\title{
OD SEULU DO SYDNEY - POLITYCZNY WYMIAR IGRZYSK OLIMPIJSKICH 1988-2000
}

W ostatnich dwóch dekadach XX wieku świat przechodził fundamentalne zmiany społeczno-polityczne zarówno w globalnym, jak i lokalnym wymiarze. Postępująca degrengolada systemu komunistycznego, która doprowadziła do emancypacji narodów w Europie Środkowo-Wschodniej, a następnie spowodowała rozpad Związku Socjalistycznych Republik Sowieckich, w konsekwencji zakończyła rozpoczęty po II wojnie światowej „,zimnowojenny” konflikt. Koniec wielowymiarowej rywalizacji między Wschodem a Zachodem, między system komunistycznym a kapitalistycznym, determinował do podjęcia wysiłków celem ułożenia nowego porządku światowego. Jednocześnie odsłonił lub wygenerował wiele lokalnych problemów i konfliktów w różnych zakątkach ziemskiego globu, jak np. wojna w byłej Jugosławii.

Przełomowe zmiany w przestrzeni międzynarodowej oddziaływały w znaczący sposób także na świat sportu. Będący jego emanacją ruch olimpijski, ufundowany na idealistycznych założeniach egalitaryzmu i neutralności politycznej, musiał się więc z nimi zmierzyć. Niniejszy artykuł jest próbą zarysowania politycznych problemów i sposobów ich rozwiązywania przez Międzynarodowy Komitet Olimpijski w latach 1988-2000, czyli w okresie organizacji czterech letnich igrzysk olimpijskich: w Seulu, Barcelonie, Atlancie i Sydney¹. Stanowiły one zwieńczenie fascynującej historii dynamicznie rozwijającego się ruchu olimpijskiego w XX wieku.

\footnotetext{
* DR RAfaŁ Jung - Katedra Teorii Polityki i Myśli Politycznej, Wydział Studiów Międzynarodowych i Politologicznych, Uniwersytet Łódzki, e-mail:rjung@uni.lodz.pl.

${ }^{1}$ Ograniczenie się do przedstawienia politycznej historii przede wszystkim letnich igrzysk olimpijskich w tym okresie wynika z okoliczności, że są one postrzegane jako najważniejsze, najbardziej prestiżowe ze wszystkich zawodów sportowych organizowanych we współczesnym świecie. Wyróżniają się one ze względu na liczbę sportowców, obserwującej ich publiczności oraz wielkie zainteresowanie mediów. W związku z tym letnia formuła ma dużo większe znaczenie polityczne aniżeli zimowe igrzyska olimpijskie, które ze względu na ograniczenia lub wręcz brak możliwości uprawiania sportów zimowych w wielu rejonach świata ze względów geograficznych są mniej popularne, budząc mniejsze zainteresowanie światowej opinii publicznej.
} 
IGRZYSKA XXIV OLIMPIADY - SEUL 1988

Po swoistym cyklu bojkotów z powodów politycznych letnich igrzysk olimpijskich w Montrealu (1976), a przede wszystkim w Moskwie (1980) i Los Angeles (1984), będących skutkiem i niejako odwzorowaniem „zimnowojennego" konfliktu, pod koniec lat 80 . XX wieku pojawiła się szansa na wspólny udział sportowców z przeciwstawnych bloków ideologicznych w największej imprezie sportowej świata. Tę możliwość stworzyło wyraźne odprężenie na linii Wschód-Zachód, szczególnie w relacjach sowiecko-amerykańskich, które było następstwem zmiany polityki Kremla w zakresie stosunków wewnętrznych, jak i międzynarodowych. Autorem i realizatorem nowej koncepcji politycznej, która miała reanimować niewydolny system sowiecki, był Michaił Gorbaczow, od 1985 r. Sekretarz Generalny KC KPZR, wprowadzający w życie politykę pieriestrojki i głasnosti.

Polityka Gorbaczowa w istotny sposób ułatwiła misję prezydentowi MKOl, Juanowi Antonio Samaranchowi. Ten Katalończyk, w przeszłości wysoki funkcjonariusz reżimu Francisco Franco (m.in. minister sportu, gubernator Katalonii oraz pierwszy w epoce postfrankistowskiej ambasador Hiszpanii w ZSRS), zastępując po igrzyskach w Moskwie Michaela lorda Killanina na najwyższym stanowisku w ruchu olimpijskim, stanął przed trudnym zadaniem odbudowania jedności ruchu. Porażka (pomimo sukcesu w warstwie organizacyjno-sportowej) igrzysk w Los Angeles, ze względu na bojkot ze strony większości krajów bloku sowieckiego, mogła oznaczać trwałą dysfunkcję ruchu olimpijskiego w przypadku kolejnego takiego zdarzenia ${ }^{2}$.

Zadanie przezwyciężenia podziałów w MKOl mogło się okazać tym trudniejsze, że Komitet powierzył w $1981 \mathrm{r}$. organizację Igrzysk XXIV Olimpiady stolicy Korei Południowej, Seulowi. Korea była obok Niemiec najbardziej widocznym skutkiem „zimnowojennego” konfliktu: istniejące tam dwa państwa, Korea Płd. i komunistyczna Koreańska Republika Ludowo-Demokratyczna znajdowały się od 1953 r. formalnie w stanie wojny, będąc pod wpływem odpowiednio bloku zachodniego (na południu stacjonowały wojska USA, wyposażone m.in. w broń jądrową krótkiego zasięgu) oraz komunistycznego (ZSRS i przede wszystkim Chińskiej Republiki Ludowo-Demokratycznej). Permanentne napięcie polityczne na Półwyspie Koreańskim skutkowało m.in. brakiem stosunków dyplomatycznych Korei Płd. z państwami komunistycznymi, sytuację ponadto komplikował fakt sprawowania władzy w Seulu przez wojskową dyktaturę Chun Doo Hwana. Niemniej mimo tych istotnych politycznych przeszkód, za kandydaturą Seulu optował J. A. Samaranch. Sternik światowego ruchu olimpijskiego umiejętnie wykorzystał

${ }^{2}$ D. Miller, Historia igrzysk olimpijskich i MKOl. Od Aten do Pekinu 1894-2008, Poznań 2008, s. 290. W przypadku zimowych igrzysk olimpijskich w Sarajewie (1984) i w Calgary (1988) sportowcy ze Wschodu i Zachodu mogli rywalizować bez politycznych podtekstów. 
szansę, jaka pojawiła się wraz z objęciem władzy na Kremlu przez M. Gorbaczowa, przekonując ostatecznie decydentów w państwach komunistycznych o potrzebie wystawienia reprezentacji narodowych na seulskie igrzyska. Inna rzecz, że w tzw. demoludach zdawano sobie sprawę z negatywnych konsekwencji absencji swoich sportowców na kolejnych igrzyskach w postaci niezadowolenia przyzwyczajonej do sukcesów sportowych swoich zawodników opinii publicznej w tych krajach?3

$\mathrm{Na}$ bardziej pryncypialne stanowisko krajów komunistycznych, szczególnie ZSRS i ChRL, w kwestii udziału w igrzyskach w Seulu liczyły jednak władze KRL-D. Od 1984 r. podejmowały one różne wysiłki, których głównym celem było uniemożliwienie organizacji igrzysk na południu. Począwszy od długotrwałych negocjacji w sprawie współorganizacji igrzysk w obu częściach Korei (proponując kuriozalną z punktu widzenia Statutu MKOl formułę Koreańskich Igrzysk Olimpijskich bądź Phenian-Seul-Korea-Olimpiady), czy powołania wspólnej reprezentacji, po propagandowe ataki na ideę rozegrania igrzysk w Seulu z wzywaniem do ich bojkotu włącznie. W kalkulacjach Phenianu sukces tej imprezy wzmocniłby międzynarodową pozycję ich południowego sąsiada, czyniąc problematycznym zjednoczenie Korei na dogodnych dla północnokoreańskich komunistów warunkach. Działacze MKOl byli skłonni przystać jedynie na propozycję rozegrania kilku konkurencji olimpijskich na północy półwyspu oraz wspierali pomysł powołania wspólnej reprezentacji. Niemniej mając pewność, że nie dojdzie do bojkotu ze strony formalnie popierających postulat Korei Płn. w sprawie współorganizacji igrzysk państw bloku komunistycznego, przedłużali niewiele znaczące negocjacje obu państw koreańskich niemalże do samej inauguracji igrzysk 4 .

Ostatecznie władze KRL-D odmówiły udziału swoich sportowców w seulskich igrzyskach, a tamtejsze media w ogóle przemilczały moment otwarcia zawodów, informując jedynie o... epidemii cholery w Seulu, która zbierała śmiertelne żniwo i zmuszała olimpijczyków do ucieczki z miasta. Nieco naiwne nadzieje także wśród niektórych działaczy MKOl, że igrzyska olimpijskie w Seulu mogą przyczynić się do zbliżenia obu państw koreańskich i określić niedaleką perspektywę ich zjednoczenia, znalazły jedynie symboliczny wymiar podczas ceremonii otwarcia, gdy w czasie widowiska zainscenizowano walkę dwóch grup ludzi, które ostatecznie doprowadzają do przyjaznego porozumienia ${ }^{5}$.

W imię solidarności z KRL-D do Azji nie przybyła ekipa Kuby - co nie było zaskoczeniem zważywszy na fakt jednoznacznego od samego początku poparcia północnokoreańskiego stanowiska ze strony Fidela Castro - oraz reprezentanci Etiopii, Libii i Nikaragui ${ }^{6}$. W Seulu nie pojawili się także sportowcy z Albanii, gdzie nie

${ }^{3}$ M. M. Kobierecki, „Sportowa wojna światowa”. Implikacje polityczne międzynarodowej rywalizacji sportowej w okresie zimnej wojny, Łódź 2017, s. 271-275.

${ }^{4}$ M. Słoniewski, Bojkot igrzysk olimpijskich jako instrument polityki międzynarodowej w latach 1976-1988, Warszawa 2016, s. 299 i n.

${ }^{5}$ Kronika Sportu, red. M. B. Michalik, Warszawa 1993, s. 796.

${ }^{6}$ M. M. Kobierecki, ,Sportowa wojna..., s. 275. 
dotarły jeszcze echa pieriestojki. Niemniej rekordowa liczba 159 państw uczestniczących w drugich w historii igrzyskach w Azji była sukcesem J. A. Samarancha i MKOl-u - po raz pierwszy od 1976 r. na najważniejszej imprezie sportowej świata rywalizowali zawodnicy ze Wschodu i Zachodu?

Także dla gospodarzy Igrzyska XXIV Olimpiady, które odbyły się w dniach 17 września - 2 października 1988 r., zakończyły się wielowymiarowym sukcesem. Przede wszystkim stały się istotnym wsparciem dla procesu demokratyzacji kraju, który został zainicjowany przed igrzyskami, także w wyniku wielotysięcznych demonstracji, poprzez przeprowadzenie w 1988 wolnych wyborów prezydenckich (prezydenta Chun Doo Hwana zastąpił wówczas szef Komitetu Organizacyjnego Igrzysk w Seulu, Roh Tae Woo) i parlamentarnych oraz uchwalenie nowej konstytucj. Organizacja kluczowej imprezy sportowej wraz ze zmianami politycznymi przyśpieszyły z kolei proces otwierania się Korei Płd. na świat, w tym na kraje komunistyczne, z którymi Seul zaczął nawiązywać stosunki dyplomatyczne. Dla degradujących się ekonomicznie krajów bloku wschodniego miały one o tyle istotne znaczenie, że inicjowały możliwość współpracy gospodarczej. Korea Płd. bowiem poprzez niemal perfekcyjną organizację igrzysk ( $\mathrm{z}$ budżetem na poziomie ponad 3 mld dolarów) pokazała ogromny potencjał gospodarczy. Rozbudowa infrastruktury i transfery finansowe dzięki igrzyskom bardzo korzystnie wpłynęły na rozwój tamtejszej gospodarki, dzięki czemu Koreę Płd. zaczęto zaliczać do elitarnego grona gospodarczych ,azjatyckich tygrysów”.

W wymiarze sportowym Koreańczycy z południa także odnieśli sukces - w nieoficjalnej klasyfikacji medalowej zajęli czwarte miejsce, tuż za potęgami sportowymi: ZSRR, NRD i USA ${ }^{9}$ - choć podważany w związku z zarzutami o nadmierną w stosunku do ich sportowców przychylność sędziów. Igrzyska 1988 r. zapisały się także licznymi aferami dopingowymi o skali niespotykanej w dotychczasowej historii zawodów olimpijskich ${ }^{10}$.

IGRZYSKA XXV OLIMPIADY - BARCELONA 1992

Igrzyska w Seulu były ostatnimi, w których uczestniczył „zimnowojenny” świat. Cztery lata później pierwsze dwa kraje w klasyfikacji medalowej południowokoreańskich igrzysk już nie istniały w dotychczas znanym kształcie. Po upadku

${ }^{7}$ R. Falewicz, Historia igrzysk olimpijskich, Poznań 2004, s. 127; Seul 1988, www.olimpijski. pl/pl/243,seul-1988.html, [dostęp: 25.02.2017].

${ }_{8}^{8}$ M. Słoniewski, Bojkot igrzysk..., s. 352-356.

9 R. Falewicz, Historia igrzysk..., s. 135.

${ }_{10}$ Seul'88, red. S. Grzegorczyk, R. Starzyński, S. Sikora, J. Żemantowski, Warszawa 1988, s. 12 i $20-24$. 
komunizmu w Europie Środkowo-Wschodniej, który był skutkiem „Jesieni Ludów” 1989 r., doszło do znaczących korekt na mapie politycznej Starego Kontynentu, które przyniosły rozmaite konsekwencje także dla międzynarodowego ruchu olimpijskiego.

Podczas XVI Zimowych Igrzysk Olimpijskich w 1992 r. we francuskim Albetville wystąpiła po raz pierwszy od $1936 \mathrm{r}$ - - i od razu zwycięska - reprezentacja zjednoczonych Niemiec. Formalnie pod nazwą Republiki Federalnej Niemiec, będącą skutkiem włączenia 3 października 1990 r. NRD w struktury państwowe (tym samym i sportowe) RFN. Drugie miejsce w klasyfikacji medalowej zajęli sportowcy ze Wspólnoty Niepodległych Państw, występujący pod flagą olimpijską. Reprezentowali oni na igrzyskach, na mocy porozumienia J. A. Samarancha i prezydenta Rosji Borysa Jelcyna, nowy twór polityczny powstały pod koniec $1991 \mathrm{r}$. po rozwiązaniu ZSRS. Ekipa ta, mająca nieco kuriozalny charakter, zgromadziła sportowców z republik postsowieckich ${ }^{11}$, z wyjątkiem Litwy, Łotwy i Estonii. Państwa bałtyckie tym samym, pierwszy raz od lat 30 . XX wieku, uczestniczyły w zawodach olimpijskich jako suwerenne państwa. W Albertville, po raz pierwszy w historii igrzysk olimpijskich, wystąpiły zaś reprezentacje Chorwacji i Słowenii, które uzyskały niepodległość w wyniku rozpoczętej w 1991 r. wojny domowej w Jugosławii. Sportowcy z tego upadłego państwa - głównie Serbowie - we Francji nie wystąpili, natomiast na letniej olimpiadzie 1992 r., wskutek sankcji Organizacja Narodów Zjednoczonych nałożonych na Jugosławię po eskalacji konfliktu na Bałkanach, decyzją MKOl rywalizowali pod flagą olimpijską jako osoby prywatne. Tymczasowe członkostwo w Komitecie przyznano zaś Bośni i Hercegowinie, odmówiono go z kolei Macedonii ze względu na spór z Grecją o nazwę tej byłej republiki jugosłowiańskiej.

XXV Letnie Igrzyska Olimpijskie odbyły się w dniach 25 lipca - 9 sierpnia 1992 r. w rodzinnym mieście J. A. Samarancha, w Barcelonie. Co oczywiste, wspierał on tę kandydaturę - było to czwarte w ciągu ostatnich sześćdziesięciu lat podejście tego miasta do organizacji igrzysk - lecz czynił to jednak na tyle dyskretnie, by nie zostać posądzonym o stronniczość ${ }^{12}$. Marzeniem prezydenta MKOl było, aby okazały się one wzorcowymi pod każdym względem. I w znacznej mierze się to powiodło: odbyły się bez bojkotów politycznych - z udziałem rekordowej liczby 171 krajów; bez aktów terrorystycznych - mimo zapowiedzi ze strony baskijskich separatystów z organizacji ETA ${ }^{13}$; i praktycznie bez skandali dopingowych. A do tego w przyjaznej i romantycznej atmosferze „bajkowego miasta szalonego architekta" Antonio Gaudiego. Ważnym gestem politycznym, który miał jednoczyć Hiszpanów, było przemówienie króla Juana Carlosa I po katalońsku

${ }^{11}$ Podczas dekoracji zwycięzców sportowcy ze WNP „przemieniali się” w Rosjan, Białorusinów, Ukraińców itd. i odpowiednio do reprezentowanych nacji podnoszono na maszt flagi i odgrywano hymny narodowe. Kronika..., s. 853.

${ }_{12}$ D. Miller, Historia igrzysk..., s. 295.

${ }_{13}$ Barcelona'92. Igrzyska bez tajemnic, wyd. specjalne „Świata Młodych” pod patronatem PKOl, Warszawa 1992, s. 11. 
w czasie ceremonii otwarcia igrzysk na Stadionie Olimpijskim na wzgórzu Monjuic. Igrzyska w Barcelonie, zorganizowane w 500. rocznicę odkrycia Ameryki przez Krzysztofa Kolumba, podkreśliły rosnące znaczenie międzynarodowe Hiszpanii, szczególnie w świecie hiszpańskojęzycznym, co było konsekwencją skutecznej w wielu wymiarach polityki kolejnych rządów w Madrycie przezwyciężającej po 1975 r. skutki dyktatury F. Franco.

Znaczącym wydarzeniem igrzysk był występ - po raz pierwszy od 1960 r. - reprezentacji Republiki Południowej Afryki. Było to możliwe dzięki konsekwentnemu demontażowi przez prezydenta tego kraju, Frederika de Klerka, przy znaczącym współudziale przewodniczącego Afrykańskiego Kongresu Narodowego, Nelsona Mandeli, systemu segregacji rasowej w tym kraju. Po powołaniu w MKOl w 1988 r. Komisji ds. Apartheidu i Olimpizmu, licznych negocjacjach i zwieńczającej je wizycie J. A. Samarancha w RPA w marcu 1990 r., państwo to w lipcu 1991 r. ponownie przyjęto do rodziny olimpijskiej ${ }^{14}$. W Hiszpanii ekipa południowoafrykańska wystąpiła jako zintegrowany pod względem rasowym zespół. Nie odegrał on większej roli w olimpijskiej rywalizacji, podobnie jak reprezentacja Albanii, która pierwszy raz od 1972 r. uczestniczyła w igrzyskach.

Pomimo wielkich problemów politycznych i gospodarczych, jakie na początku lat 90. XX wieku objawiły się w przestrzeni postsowieckiej, w barcelońskich igrzyskach triumfowali sportowcy WNP, wyprzedzając Amerykanów i „zjednoczonych” już Niemców ${ }^{15}$.

IGRZYSKA XXVI OLIMPIADY - ATLANTA 1996

Kolejne igrzyska olimpijskie, na podstawie decyzji MKOl z 1986 r. o zaniechaniu organizowania zimowych i letnich zawodów w tym samym roku czteroletniego cyklu olimpijskiego, lecz co dwa lata, odbyły się już w 1994 r. Zimowe, w dużej mierze ekologiczne i kameralne igrzyska, przeprowadziło wówczas norweskie Lillehammer.

Zawody w Skandynawii otwierały obchody stulecia międzynarodowego ruchu olimpijskiego. Z tej okazji MKOl został specjalnie uhonorowany przez Zgromadzenie Ogólne ONZ, które przyjęło rezolucję „Budowa pełnego pokoju i lepszego świata poprzez sport i ideały olimpijskie”. W 1995 r. podczas 50. Sesji na forum ONZ J. A. Samaranch wystąpił jako pierwszy w historii przedstawiciel organizacji

${ }^{14}$ D. Miller, Historia igrzysk..., s. 318-320.

${ }^{15}$ Co ciekawe, reprezentacja zjednoczonych Niemiec podczas LIO 1992 zdobyła dwa razy mniej medali niż na poprzednich igrzyskach łącznie ekipy NRD i RFN. R. Falewicz, Historia igrzysk..., s. 135 i 144. 
pozarządowej. Wydarzenia te świadczyły o szacunku i prestiżu, jaki zdobył sobie ruch olimpijski, potwierdzając swą ważną, niejako polityczną rolę w działaniach na rzecz kreowania pokoju na świecie.

Z kolei w 1996 r. ruch olimpijski obchodził stulecie nowożytnych igrzysk olimpijskich. W związku z tym powszechne było przekonanie, że Igrzyska XXVI Olimpiady zostaną zorganizowane w Atenach. W MKOl zdawano sobie jednak sprawę, że stolica Grecji znacznie ustępowała pod względem możliwości organizacyjnych i finansowych innym kandydaturom, przede wszystkim Atlancie, Melbourne i Toronto. Ostatecznie w 1990 r. zdecydowano powierzyć zaszczyt przeprowadzenia igrzysk Atlancie w amerykańskim stanie Georgia. Opinia publiczna na świecie przyjęła ten wybór bardzo krytycznie, doszukując się nieczystych intencji członków MKOl, którzy postanowili wybrać kandydaturę wspieraną przez wielkie amerykańskie koncerny, przede wszystkim Coca-Colę, kosztem tradycji i symboliki olimpijskiej ${ }^{16}$.

W czasie igrzysk w Atlancie, które przeprowadzono w dniach 19 lipca - 4 sierpnia 1996 r., rywalizowało 197 krajów. Tak jak w Lillehammer, nie wystąpiły reprezentacje WNP i Czechosłowacji, co nie oznaczało jednak bojkotu imprezy z ich strony. W przypadku WNP zrezygnowano ze sztucznej formuły wielonarodowego tworu podczas igrzysk na rzecz narodowych reprezentacji państw postsowieckich, które w połowie lat 90 . XX wieku były mniej lub bardziej, ale już niezależne od Moskwy $^{17}$. Mimo nowych realiów Rosja pozostała jednak nadal potęgą sportową (podczas ZIO 1994 w klasyfikacji medalowej zajęła 1. miejsce, przed Norwegią i Niemcami, a w LIO 1996 - 2. miejsce, za USA, a przed Niemcami). Natomiast brak reprezentantów Czechosłowacji był spowodowany „aksamitnym rozwodem” Słowaków z Czechami, który dokonał się 1 stycznia 1993 r., co skutkowało debiutem olimpijskim ich narodowych ekip już w Norwegii. W Skandynawii po raz pierwszy wystąpiła także reprezentacja Bośni i Hercegowiny, a do rangi jej symbolu - już podczas olimpijskich zawodów w Atlancie - pretendował maratończyk Islam Djugum, który uczestnicząc w walkach na terenie byłej Jugosławii, jednocześnie przygotowywał się do występu w Atlancie. W USA zadebiutowali także

${ }^{16}$ D. Miller, Historia igrzysk..., s. 313-314 i 348. Polski historyk sportu i ceniony znawca olimpizmu W. Lipoński (Historia sportu na tle rozwoju kultury fizycznej, Warszawa 2012, s. 599) stwierdził wprost, że za wyborem Atlanty stała „akcja łapówkowa” przeprowadzona przez amerykańskiego członka MKOl Roberta Helmicka. Miał on przekupić innych członków gremium decydującego o wyborze gospodarza igrzysk w 1996 r. pieniędzmi pozyskanymi od amerykańskich koncernów.

17 W ten sposób podczas ZIO 1994 i/lub LIO 1996 zadebiutowały na igrzyskach ekipy Armenii, Azerbejdżanu, Białorusi, Gruzji, Kazachstanu, Kirgistanu, Mołdawii, Turkmenistanu, Tadżykistanu, Ukrainy i Uzbekistanu. Symbolicznym wymiarem ewolucji politycznej na obszarze byłego ZSRS był fakt, że chorąży ekipy rosyjskiej podczas LIO 1996, zapaśnik Aleksandr Karelin spełniał tę funkcję w trzech ekipach olimpijskich: w Seulu niósł flagę ZSRS, w Barcelonie - WNP, a w Atlancie - Rosji. Atlanta 1996, www.olimpijski.pl/pl/247,atlanta-1996.html, [dostęp: 1.03.2017]. 
sportowcy z Macedonii. Natomiast Serbowie i Czarnogórcy - po cofnięcia sankcji ONZ - przyjechali do Atlanty pod szyldem Nowej Jugosławii ${ }^{18}$.

Igrzyska XXVI Olimpiady stały się również miejscem debiutu reprezentacji Palestyny, co było konsekwencją ustanowienia Autonomii Palestyńskiej w 1994 r. na mocy porozumień z Oslo' ${ }^{19}$.

W zamyśle organizatorów zawody w Atlancie - dosyć kłopotliwe dla ich uczestników z powodu rozrzucenia obiektów olimpijskich na znacznej przestrzeni - miały odzwierciedlać wielokulturowość amerykańskiego południa. W związku z ich organizacją uruchomiono wiele programów społecznych skierowanych do społeczności murzyńskiej i kobiet. W tym kontekście symbolicznie znaczenie miał fakt powierzenia zapalenia znicza olimpijskiego legendarnemu czarnoskóremu pięściarzowi Muhammadowi Ali, od lat zmagającemu się z chorobą Parkinsona ${ }^{20}$.

Paradoksalnie, ideę poprawnych politycznie igrzysk zakłócił biały, chrześcijański fundamentalista, który przeprowadził w centrum Atlanty atak terrorystyczny. W nocy z 26 na 27 lipca 1996 r. w Centennial Park w wyniku wybuchu bomby zginęły dwie postronne osoby, a 110 zostało rannych. Terrorystą okazał się Amerykanin Eric Rudolph, który w ten sposób wyraził sprzeciw wobec rządu USA, dopuszczającego możliwość wykonywania aborcji na życzenie ${ }^{21}$. Atak, nie tak spektakularny jak w Monachium, nie zakłócił olimpijskiej rywalizacji, ale po raz kolejny zwrócił uwagę na problem terroryzmu wykorzystującego dla swoich celów wielkie imprezy sportowe.

\section{IGRZYSKA XXVII OLIMPIADY - SYDNEY 2000}

Ostatnie w XX wieku zimowe igrzyska olimpijskie MKOl odbyły się w japońskim Nagano (w klasyfikacji medalowej zwyciężyła RFN, przed Norwegią i Rosją) ${ }^{22}$.

Natomiast letnie igrzyska, po 44 latach, ponownie zawitały na Antypody. Po bardzo upolitycznionych zawodach olimpijskich w Melbourne w 1956 r., zaszczyt ten przypadł innemu australijskiemu miastu, Sydney. Jego kandydatura wygrała w 1993 r. konkurencję z Manchesterem, Berlinem, Stambułem i nieznacznie z Pekinem. Australijczycy przedstawili unikalną propozycję łączącą walory geograficzne Sydney, zakładany ekologiczny charakter igrzysk, przede wszystkim w zakresie

${ }^{18}$ R. Falewicz, Historia igrzysk..., s. 154.

${ }_{19}$ www.sports-reference.com/olympics/countries/PLE/summer/1996/, [dostęp: 5.03.2017].

${ }^{20}$ D. Miller, Historia igrzysk..., s. 349-351.

${ }^{21}$ www.terroryzm.com/article/165/Zamachy-terrorystyczne-przeciwko-Stanom-Zjednoczonym. html, [dostęp: 29.10.2008].

22 R. Falewicz, Historia igrzysk..., s. 214. 
infrastruktury sportowej, multikulturowość miejsca, podkreśloną siłą i reputacją sportową Australijczyków ${ }^{23}$.

Wielokulturowość nie tylko Sydney, lecz całej Australii stała się, jak się okazało, najważniejszym problemem społeczno-politycznym związanym z Igrzyskami XXVII Olimpiady. Na plan pierwszy wysunęła się bowiem kwestia rdzennych mieszkańców kontynentu - Aborygenów. Już od momentu przygotowywania kandydatury Sydney pojawiały się opinie, później także protesty, mające zwrócić uwagę opinii światowej na dramatyczne położenie tej grupy etnicznej w zdominowanym przez Anglosasów kraju. Chodziło w szczególności o nieskuteczną w zakresie asymilacji, a w różnych okresach historycznych nawet brutalną politykę kolejnych rządów australijskich w stosunku do Aborygenów (tzw. stracone pokolenie) oraz ważną kwestię zwrotu ziem należących niegdyś do tej mniejszości etnicznej.

Motywy aborygeńskie zostały szeroko wykorzystane przy promocji i wizualizacji igrzysk oraz na samej imprezie. Począwszy od stworzenia logotypów kandydatury, a później igrzysk, po symboliczne gesty związane ze sztafetą z ogniem olimpijskim (miała ona swój początek w Australii w świętym miejscu Aborygenów Uluru) oraz w trakcie widowisk otwierających i zamykających igrzyska. Niemniej najważniejszymi dla Aborygenów były wydarzenia związane z udziałem czołowej lekkoatletki australijskiej, z pochodzenia Aborygenki, Cathy Freeman. Organizatorzy powierzyli jej zapalenie znicza olimpijskiego w czasie ceremonii inauguracji igrzysk. Natomiast po biegu finałowym na 400 m, który zakończyła zwycięstwem, dokonała swoistej demonstracji politycznej, manifestując swą radość przy użyciu flagi australijskiej i aborygeńskiej. Już po zakończeniu kariery sportowej lubiana i szanowana przez większość Australijczyków C. Freeman stała się główną orędowniczką sprawy aborygeńskiej. Jej działania w ramach specjalnie powołanej fundacji zaczęły przynosić efekty kilka lat po igrzyskach. Zwrócenie uwagi na problem Aborygenów w czasie zawodów olimpijskich w Sydney przyczyniło się jednak do rozpoczęcia procesu pojednania między Australijczykami a Aborygenami. Jego kulminacyjnym momentem było przemówienie premiera Australii, Kevina Rudda w lutym 2008 r. w parlamencie, w którym przeprosił on Aborygenów za dyskryminację i prześladowania. Proces ten jest jednak trudny i do dzisiaj nie przyniósł, szczególnie w sferze instytucjonalno-prawnej, satysfakcjonujących rozwiązań dla tej grupy etnicznej24.

Ważnym wydarzeniem o charakterze politycznym w czasie igrzysk w Sydney, które odbyły się w dniach 15 września - 1 października 2000 r., był wspólny przemarsz reprezentacji obu Korei podczas ceremonii otwarcia imprezy. Był on możliwy dzięki ustaleniom pierwszego w historii szczytu koreańskiego, który odbył się w czerwcu 2000 r. w Phenianie z udziałem prezydenta Korei Płd., Kim De

${ }^{23}$ D. Miller, Historia igrzysk..., s. 335.

24 A. Zalewski, Polityczna wymowa XXVII Letnich Igrzyska Olimpijskich Sydney 2000, Łódź 2013, (maszynopis), s. 21 i n. 
Dzunga i lidera KRL-D, Kim Dzong Ila oraz późniejszych mediacji J.A. Samarancha w czasie rozmów między dyplomatami z obu części Korei w tej sprawie.

15 września 2000 r. sportowcy z obu koreańskich ekip przemaszerowali wspólnie pod wskaźnikiem z nazwą „Korea”, a przewodzili im szefowie komitetów olimpijskich obu państw - Kim Un-Yong z Korei Płd. oraz Chang Ung z KRL-D. Zunifikowana na ten jednorazowy występ reprezentacja została ubrana w jednolite stroje: ciemne marynarki, jasne spodnie lub spódnice i pomarańczowe krawaty. Co najważniejsze, pojawiła się na Stadium Australia pod jedną flagą tzw. zjednoczeniową, na której na białym tle widniał niebieski zarys Półwyspu Koreańskiego wraz z wyspą Cheju. Nieśli ją wspólnie północnokoreański trener judo, Pak Jung Chul oraz koszykarka z Korei Płd., Chung Eun-sun. Operatorzy kamer robili zbliżenia na złączone dłonie koreańskich sportowców, symbolizujące swoisty marsz ku jedności, co spotkało się z owacją obecnej na stadionie publiczności ${ }^{25}$.

Komentatorzy uznali to symboliczne wydarzenie jako przełomowy moment w historii relacji międzykoreańskich, dające nadzieję na rozpoczęcie procesu zjednoczeniowego między KRL-D i Koreą Płd., nawet pomimo faktu, że w zawodach olimpijskich oba kraje wystawiły oddzielnie reprezentacje pod własnymi symbolami państwowymi. I choć jeszcze na Igrzyskach Azjatyckich w Pusan w 2002 r. Koreańczycy przemaszerowali pod jedną flagą, negocjacje na temat powołania wspólnej reprezentacji na wielkie imprezy sportowe w ciągu kolejnych lat nie przyniosły żadnego efektu. Podobnie jak dialog na temat zjednoczenia Korei. Wydaje się, że ów dający nadzieję gest, jaki miał miejsce w Sydney, był elementem strategii rządzącej Koreą Płn. dynastii Kimów, realizującej określone cele polityczne w przestrzeni międzynarodowej.

Na milenijnych igrzyskach zadebiutowali sportowcy z Timoru Wschodniego. Miało to paradoksalny wymiar, gdyż Australia była jedynym krajem obok USA, które uznały aneksję zamieszkałego w przeważającej części przez chrześcijan Timoru przez muzułmańską Indonezję w 1976 r. ${ }^{26} \mathrm{~W}$ Sydney sportowcy z tego terytorium, znajdującego się wówczas pod administracją ONZ po referendum niepodległościowym z 1999 r., wystąpili jeszcze pod flagą MKOl-u jako Niezależni Sportowcy Olimpijscy. W 2002 r. po ogłoszeniu niepodległości stali się już równoprawnymi członkami rodziny olimpijskiej.

Musieli natomiast ją czasowo opuścić, nie uczestnicząc w igrzyskach w Sydney, sportowcy z Afganistanu. Wskutek przejęcia władzy przez talibów wkrótce po zakończeniu igrzysk w Atlancie, w opartym na ortodoksyjnym prawie szariatu, ksenofobicznym i izolowanym państwie nie było przyzwolenia władz na uprawianie sportu. Afgańscy sportowcy wrócili na olimpijskie areny dopiero w 2004 r., po upadku reżimu talibów w następstwie amerykańskiej interwencji w Afganistanie rozpoczętej w $2001 \mathrm{r}$.

${ }^{25}$ www.youtube.com/watch?v=J-QivSECfj4, [dostęp: 3.08.2012].

${ }^{26}$ Ł. Bonczol, Timor Wschodni. Od reliktu kolonializmu do problemu międzynarodowego, Wrocław 2008, s. 71. 
Deszczowe, oraz znów z problemem dopingu w tle, australijskie igrzyska, w których uczestniczyła rekordowa liczba 199 państw, zakończyły się ostatecznym triumfem ekipy USA, przed Rosją i Chinami ${ }^{27}$. Milenijne igrzyska były ostatnimi dla Juana Antonio Samarancha w roli szefa MKOl - w 2001 r. zastąpił go były żeglarz, lekarz i działacz sportowy, Belg Jacques Rogge.

\section{WNIOSKI}

Dla międzynarodowego ruchu olimpijskiego lata 1988-2000 były czasem wielu politycznych wyzwań: szczególnie do połowy lat 90. XX wieku, kiedy świat przechodził burzliwe przemiany polityczne. Igrzyska w Seulu, które będąc swoistym katharsis po masowych bojkotach igrzysk w Moskwie i Los Angeles, gdy sportowcy z niemalże całego świata bez względu na podziały polityczne znów zaczęli rywalizować na bieżniach, matach i boiskach olimpijskich, stanowiły zwieńczenie historii „zimnej wojny” w przestrzeni sportowej. To, że nie doszło wówczas do kolejnego masowego bojkotu najważniejszej imprezy sportowej z powodu problemu koreańskiego należy uznać za ogromny sukces MKOl.

Rywalizacja niemalże całego sportowego świata w Seulu miała zapowiadać erę końca historii, w której szlachetna rywalizacja sportowa miała przebiegać bez podtekstów politycznych. Rzeczywistość zadała kłam tym nadziejom. Kolejne zawody olimpijskie przede wszystkim w letniej formule w mniejszym czy większym wymiarze stanowiły odbicie przede wszystkim regionalnych konfliktów politycznych i społecznych ówczesnego świata. Najwięcej problemów przysporzyły MKOl konsekwencje związane zarówno z krwawą wojną w byłej Jugosławii, jak i z bezkonfliktowym, patrząc na całość procesu, rozpadem ZSRS. Wiązało się to z kwestią dopuszczenia do igrzysk dużej liczby nowych państw powstałych w wyniku zmian na politycznej mapie Eurazji, z uwzględnieniem decyzji politycznych wobec niektórych z nich (Serbia i Czarnogóra, Timor Wschodni), które podejmowała ONZ, a które MKOl respektował w swych postanowieniach. Między innymi za takie paralelne działanie Komitet został wyróżniony w stulecie swojego istnienia przez Narody Zjednoczone.

Kwestia udziału państw w igrzyskach olimpijskich, także tych nowopowstałych, jest jednym z zasadniczych zagadnień w politologicznych rozważaniach na temat sportu. Możliwość uczestnictwa sportowców w najważniejszej imprezie sportowej świata pod własnymi symbolami narodowymi niejako potwierdza legitymację ich suwerenności i podmiotowości w przestrzeni międzynarodowej. Jeśli do tego dochodzi sukces sportowy, państwa przestają być anonimowe, wzrasta

${ }^{27}$ R. Falewicz, Historia igrzysk..., s. 155 i 165. 
ich prestiż, co ma znaczenie w budowie pozytywnego wizerunku kraju. W omawianym okresie dowodzą tego przykłady państw postjugosłowiańskich, krajów bałtyckich czy nawet mało znaczącego w skali globalnej Timoru Wschodniego. $\mathrm{Z}$ tego punktu widzenia interesującym casusem był eksperyment związany z powołaniem reprezentacji Wspólnoty Niepodległych Państw na igrzyska roku 1992. Jego tymczasowość została niejako przesądzona już w momencie ustalenia praktyki celebracji medalistów olimpijskich wywodzących się z tej ekipy, co było przejawem nadzwyczajnej chęci manifestacji podmiotowości politycznej przez państwa ją tworzące. Niemniej jedna reprezentacja skupiająca sportowców z większości państw postsowieckich była wówczas rozwiązaniem korzystnym zarówno dla osłabionego centrum politycznego w Moskwie - patrząc przede wszystkim przez pryzmat osiągniętego sukcesu sportowego - jak i dla MKOl. Komitet mógł w ten sposób odwlec moment przyjęcia kolejnej dużej grupy państw, zyskując czas na dostosowanie się do nowej rzeczywistości.

Analizując zjawisko igrzysk olimpijskich z politologicznego punktu widzenia należy wziąć pod uwagę także zagadnienie wyboru przez MKOl gospodarza imprezy. Organizacja tego typu przedsięwzięcia niesie ze sobą zazwyczaj więcej korzyści nie tylko miastom, ale i państwom. Sprawna organizacja imprezy dla sportowców i oglądających ich zmagania kibiców, a także - co niebagatelne - dla przedstawicieli mediów, jeśli jest wsparta tzw. przyjazną atmosferą, buduje pozytywny, także w wymiarze politycznym, wizerunek gospodarza. Często też przynosi wymierne korzyści finansowe, choć koszty igrzysk w omawianym okresie ogromnie wzrastały. Niewątpliwie wynikało to z postępującej w epoce J. A. Samarancha komercjalizacji igrzysk. Charakteryzowała się ona coraz większym wpływem stacji telewizyjnych na program i organizację zawodów w zamian za coraz wyższe koszty nabywania praw medialnych; wprowadzeniem i konsekwentną rozbudową pakietów sponsorskich w postaci tzw. programów TOP; oraz umożliwieniem udziału w igrzyskach hojnie opłacanych sportowców z NHL, NBA czy z rankingów ATP i WTA. Proces komercjalizacji wymusił z kolei konieczność zróżnicowania w czasie organizacji letnich i zimowych igrzysk.

W latach 1988-2000 widać w poczynaniach gremium decyzyjnego MKOl w kwestii przyznawania prawa do organizacji letnich igrzysk pewną niekonsekwencję, choć może należy te działania nazwać elastycznością. Wybór Seulu niósł za sobą polityczne ryzyko związane z konsekwencjami istnienia dyktatorskiego systemu rządów w Korei Płd. Tymczasem podobne ryzyko związane z przyznaniem praw organizacji w 1993 r. igrzysk milenijnych Pekinowi - z uwagi na bliskość czasową pacyfikacji studenckich manifestacji na placu Tian'anmen w 1989 r., która oburzyła światową opinię publiczną - odsunięto daleko w czasie. Jak wskazywali obserwatorzy, zwyciężyła wówczas poprawność polityczna. Nie zdecydowano się bowiem, jak w przypadku Seulu, na swoiste działanie pedagogiczne, za którym stało przeświadczenie niektórych członków MKOl z J. A. Samaranchem na czele, że przyznanie wielkiej imprezy sportowej rozpocznie proces demokratyzacji kraju- 
-gospodarza ${ }^{28}$. Trzeba przyznać, że w przypadku Korei Płd. w znacznej mierze się to powiodło. Pozostałe wybory MKOl nie miały już tak wyraźnych politycznych konotacji. Niemniej - oprócz Sydney - przyznanie praw organizacji Barcelonie z uwagi na powinowactwo prezydenta organizacji z miastem, a szczególnie Atlancie - w miejsce „uświęconych” tradycją olimpijską Aten - można określić jako co najmniej dyskusyjne.

Przykład południowokoreański wskazywał, że MKOl jako największa organizacja pozarządowa na świecie ma ambicje, jeśli nie wprost - z uwagi na ograniczone możliwości skutecznego działania - do rozwiązywania politycznych i społecznych problemów świata, to do sygnalizowania pewnych niekorzystnych zjawisk tej natury. Świadczyły o tym także posunięcia Komitetu w dominującej w analizowanym okresie kwestii obu państw koreańskich. Podobnie, jak w przypadku sprawy aborygeńskiej w Sydney, nie okazały się one skuteczne, niemniej poprzez igrzyska, także w sposób symboliczny, zwrócono na nie uwagę opinii publicznej na świecie.

Wzrastające zainteresowanie światowej publiczności wielkimi imprezami sportowymi, jak letnie igrzyska olimpijskie, generuje również niekorzystne zjawiska natury politycznej. Do nich niewątpliwie należał kolejny akt terrorystyczny, który miał miejsce w czasie igrzysk, tym razem w Atlancie. Stanowił on jeden z serii niepokojących sygnałów zwiastujących nadejście globalnego problemu współczesnego świata, jakim jest międzynarodowy terroryzm islamski. W USA nie był to przypadek tej proweniencji, niemniej zagrożenie tym zjawiskiem wzrosło także w przestrzeni sportowej.

Politologiczna analiza działań międzynarodowego ruchu olimpijskiego w latach 1988-2000 byłaby niepełna bez podkreślenia roli kluczowego aktora, jakim był ówczesny prezydent MKOl, Juan Antonio Samaranch. Abstrahując od sprzecznych ocen dotyczących jego zaangażowania w proces komercjalizacji igrzysk, który per saldo spowodował sukces finansowy organizacji, należy zwrócić uwagę na jego równie skuteczne działania w sferze politycznej. Dzięki zręcznej dyplomacji przeprowadził on bowiem z sukcesem międzynarodowy ruch olimpijski przez z natury niepewny okres przełomowych politycznych zmian na świecie. Odtąd MKOl stał się najpotężniejszą organizacją pozarządową na naszym globie.

\section{BIBLIOGRAFIA}

\section{Opracowania:}

Barcelona'92. Igrzyska bez tajemnic, wyd. specjalne „Świata Młodych” pod patronatem PKO1, Warszawa 1992.

Ł. Bonczol, Timor Wschodni. Od reliktu kolonializmu do problemu międzynarodowego, Wrocław 2008.

R. Falewicz, Historia igrzysk olimpijskich, Poznań 2004.

${ }^{28}$ D. Miller, Historia igrzysk..., s. 334-335. 
M. M. Kobierecki, ,,Sportowa wojna światowa”. Implikacje polityczne międzynarodowej rywalizacji sportowej w okresie zimnej wojny, Łódź 2017.

Kronika Sportu, red. M. B. Michalik, Warszawa 1993.

W. Lipoński, Historia sportu na tle rozwoju kultury fizycznej, Warszawa 2012.

D. Miller, Historia igrzysk olimpijskich i MKOl. Od Aten do Pekinu 1894-2008, Poznań 2008.

Seul'88, red. S. Grzegorczyk, R. Starzyński, S. Sikora, J. Żemantowski, Warszawa 1988.

M. Słoniewski, Bojkot igrzysk olimpijskich jako instrument polityki międzynarodowej $w$ latach 1976-1988, Warszawa 2016.

A. Zalewski, Polityczna wymowa XXVII Letnich Igrzyska Olimpijskich Sydney 2000, Łódź 2013 (maszynopis).

\section{Internet:}

www.olimpijski.pl

www.sports-reference.com

www.terroryzm.com

www.youtube.com

\section{Streszczenie}

Artykuł jest próbą zarysowania politycznych problemów i sposobów ich rozwiązywania przez Międzynarodowy Komitet Olimpijski (MKOl) w latach 1988-2000, czyli w okresie organizacji czterech letnich igrzysk olimpijskich: w Seulu, Barcelonie, Atlancie i Sydney. Zwłaszcza pierwsze dwie imprezy odbyły się w przełomowym czasie zmian geopolitycznych na świecie, które w znaczący sposób oddziaływały także na świat sportu. Dzięki zręcznej dyplomacji ówczesnego prezydenta MKO1 Juana Antonio Samarancha międzynarodowy ruch olimpijski skutecznie zmierzył się z tymi problemami, stając się odtąd najsilniejszą organizacją pozarządową na naszym globie.

Słowa kluczowe: Igrzyska olimpijskie, sport, polityka, Międzynarodowy Komitet Olimpijski.

\section{FROM SEUL TO SYDNEY - THE POLITICAL DIMENSION OF THE OLYMPIC GAMES $1988-2000$}

\section{Sum mary}

The article aims to identify political problems and their solutions that were introduced by the International Olympic Committee (IOC) between 1988 and 2000. Throughout this time the Summer Olympic Games were held in Seul, Barcelona, Atlanta and Sydney. Especially the first two events took place during a critical period for the international relations. The geopolitical changes that resulted from it also significantly affected the world of sport. Thanks to clever diplomacy carried out by the IOC president, Juan Antonio Samaranch, the international olympic movement successfully handled the problems, achieving the status of the most powerful non-governmental organization in the world.

Keywords: Olympic Games, sport, politics, International Olympic Committee. 